\title{
Educational performance of children of migrant parents in Ghana, Nigeria and Angola
}

Citation for published version (APA):

Mazzucato, V., \& Cebotari, V. (2016). Educational performance of children of migrant parents in Ghana, Nigeria and Angola. Journal of Ethnic and Migration Studies, 42(5), 834-856. https://doi.org/10.1080/1369183X.2015.1125777

Document status and date:

Published: 08/04/2016

DOI:

10.1080/1369183X.2015.1125777

Document Version:

Publisher's PDF, also known as Version of record

Document license:

Taverne

\section{Please check the document version of this publication:}

- A submitted manuscript is the version of the article upon submission and before peer-review. There can be important differences between the submitted version and the official published version of record.

People interested in the research are advised to contact the author for the final version of the publication, or visit the DOI to the publisher's website.

- The final author version and the galley proof are versions of the publication after peer review.

- The final published version features the final layout of the paper including the volume, issue and page numbers.

Link to publication

\footnotetext{
General rights rights.

- You may freely distribute the URL identifying the publication in the public portal. please follow below link for the End User Agreement:

www.umlib.nl/taverne-license

Take down policy

If you believe that this document breaches copyright please contact us at:

repository@maastrichtuniversity.nl

providing details and we will investigate your claim.
}

Copyright and moral rights for the publications made accessible in the public portal are retained by the authors and/or other copyright owners and it is a condition of accessing publications that users recognise and abide by the legal requirements associated with these

- Users may download and print one copy of any publication from the public portal for the purpose of private study or research.

- You may not further distribute the material or use it for any profit-making activity or commercial gain

If the publication is distributed under the terms of Article $25 \mathrm{fa}$ of the Dutch Copyright Act, indicated by the "Taverne" license above, 


\section{Educational performance of children of migrant parents in Ghana, Nigeria and Angola}

\section{Victor Cebotari \& Valentina Mazzucato}

To cite this article: Victor Cebotari \& Valentina Mazzucato (2016) Educational performance of children of migrant parents in Ghana, Nigeria and Angola, Journal of Ethnic and Migration Studies, 42:5, 834-856, DOI: 10.1080/1369183X.2015.1125777

To link to this article: https://doi.org/10.1080/1369183X.2015.1125777

\section{Published online: 22 Dec 2015.}

Submit your article to this journal $\sqsubset$

Џll Article views: 1064

Q View related articles $\asymp$

View Crossmark data $₫$

Citing articles: 4 View citing articles ए 


\title{
Educational performance of children of migrant parents in Ghana, Nigeria and Angola
}

\author{
Victor Cebotari ${ }^{\mathrm{a}}$ and Valentina Mazzucato ${ }^{\mathrm{b}}$ \\ ${ }^{a}$ Maastricht Graduate School of Governance, Maastricht University, Maastricht, The Netherlands; ${ }^{b}$ Department \\ of Technology and Society Studies, Maastricht University, Maastricht, The Netherlands
}

\begin{abstract}
There is no empirical research on the school performance of children who live separated from their parents in sub-Saharan Africa-a major migrant sending region in the world. This study uses survey data from junior and secondary school children and youths in Ghana $(N=2760)$, Angola $(N=2243)$ and Nigeria $(N=2168)$ to examine how different transnational family formations such as internal or international parental absence accompanied by migration or divorce, who is the migrant parent and who is the caregiver, the stability of the caregiving arrangement and remittances relate with the school performance of children who stay behind. School performance is measured through an index of grades in language, mathematics and science. The results show that international parental migration (Ghana), the internal parental migration accompanied by divorce/ separation (Nigeria) and migration of both parents (Ghana and Nigeria) are likely predictors for decreased school performance. No effects are observed when parents are abroad and divorced/ separated, when only one parent migrates, when children are in a stable care arrangement or when children receive remittances or not. The analyses show that the overall relationship between parental absence and education varies by the transnational dimension being analysed and by context.
\end{abstract}

\section{ARTICLE HISTORY}

Received 6 February 2015

Accepted 24 November 2015

KEYWORDS

School performance; children

left-behind; transnational families; migrant parents; Africa

\section{Introduction}

Migration from the Global South regularly entails leaving children in the home country, hence creating a network of transnational families. When parents migrate, they are often motivated by a desire to provide better educational opportunities for children who stay behind. Remittances sent back by migrant parents may be used to paying school fees, books and other school necessities, thus enabling children to enhance their education. Yet, under certain circumstances, parental migration may affect children emotionally (Mazzucato, Cebotari et al. 2015) and potentially disrupt their performance in school.

Indeed, the transnational family literature on children's education finds contrasting evidence. Battistella and Conaco (1998) study the effects of parental migration on educational performance of children and conclude that migration negatively impacts the schooling of children in transnational care. The effects are greater for children separated from their mothers or from their primary caregivers. Similar results are found by other scholars, 
mainly targeting Latin American and Asian countries (Cortes 2015; Hu 2012; Kandel and Kao 2001; McKenzie and Rapoport 2011).

At the same time, studies note the positive effects of migration on children's education. Rapoport and Docquier (2006) find that parental migration increases the likelihood of caregivers and children receiving additional funds for the household's needs. If remittances target the younger members of the family, they can be invested in better schools, educational material and support. Research in Mexico shows that parental migration and remittances are positively associated with increased educational performance of children in transnational care (Kandel and Kao 2001; McKenzie and Rapoport 2007).

The contrasting evidence in the literature points to a more complex range of consequences of parental absence for children in transnational families. Because studies are generally small in scale and rarely consider the variety of transnational family forms, it is difficult to discern whether and how the diversity of transnational family life drives the schooling outcomes of children in transnational care. This study aims to fill this gap and make a more nuanced contribution to the analysis of school performance of children by engaging in two areas of research. Firstly, we investigate the relationship between different types of parental absence and the educational performance of children who stay behind in Ghana, Nigeria and Angola. Within this setting, we distinguish between the status of parental migration, whether internal or international, and the marital condition of the migrant parent. There is limited empirical research that looks at parental migration and the school performance of children in families affected by marital problems. We contribute to the literature by considering transnational family life in the context of marrital dissolution when measuring children's education.

Secondly, we investigate the relationships between different transnational child-raising arrangements and the school performance of children who stay at origin. The literature assesses educational performance mostly by looking at who the migrant parent is and whether migrant parents send remittances while lacking empirical data on other characteristics of children's transnational life such as who the caregiver of the child is when parents migrate or whether children live in stable caregiving arrangements following parental departure. By analysing these characteristics, we account for the complexity of migration in Africa and add precision to the analysis of transnational families. So far, most of the research on educational outcomes is conducted in Latin America-especially Mexico, and in a number of Asian countries. To date, there is no systematic empirical research on the educational performance of children in transnational families in Africa.

This study uses survey data collected in 2010-2011 among junior and senior high school children and youths between the ages of 11 and 21 . We refer to our sample population as children to emphasise the type of relationship they have with the migrant parent. The harmonised data collected in Ghana, Nigeria and Angola allow us to compare three different contexts in Africa. The inclusion of these three countries was motivated by the need for variation in a region characterised by diversity. The comparative angle permits us to observe if the findings pertain to a specific situation in a country or can be generalised to a wider regional context.

This study includes one objective measure of indexed grades for quantifying educational performance. Apart from transnational characteristics, we also focus on child and parental factors, living conditions and school mediating mechanisms underlying school performance. 


\section{Background}

\section{Migration and education of children in transnational families}

While there is a substantial interest in the outcomes of children in transnational families, theoretical input remains underdeveloped. The existent scholarship shows that parentchild separation impacts education, psychological health and the overall development of children (Jordan and Graham 2012; Mazzucato, Cebotari et al. 2015; Wen and Lin 2012). The parent-child separation has traditionally been documented by considering problematic family situations, such as divorce, abandonment and parental death (Amato and Cheadle 2005). Not until recently have scholars started paying attention to child-parent separation due to migration (Mazzucato and Schans 2011).

A large body of literature on migration and the education of children in transnational families focuses on the role of remittances on various educational outcomes. Evidence suggests that transnational households use cash from remittances to invest in children's schooling through a diversity of costs (UNDP 2009). In some Latin American countries, international migration was found to boost educational expenditures, with positive effects on children's education (Edwards and Ureta 2003), especially for girls (Antman 2012). Evidence from Philippines shows a similar pattern (Yang 2008), although recent work found that children of migrant mothers tend to lag behind in schools when controls for remittances were applied (Cortes 2015). Insofar, the positive effects of remittances on education are visible when the former are used to invest in children or to mitigate the constraints of the child labour in the households (Brown and Poirine 2005). The literature also advances the concept of 'social remittances' of knowledge and practice (Levitt 1998), which may improve children's education, except when children see migration as a more viable route for economic success than schooling (Kandel and Kao 2001).

Research shows that international parental migration positively affects children's grades in school and their educational attainment and aspirations (Kandel and Kao 2001). Using language scores as educational outcomes, Clemens and Tiongson (2013) found that parental migration has a positive impact on children attending private schools and receiving more academic awards. Results on children living in rural China show that migration generates benefits for children and increases the rate of school completion, particularly for girls ( $\mathrm{Lu} 2012$ ). Evidence also shows that paternal migration at an early stage of children's lives results in better educational attainment compared to when migration occurs later in children's lives (Antman 2012; McKenzie and Rapoport 2007). In contrast, other studies found negative consequences of parental migration on children's schooling. Using historical migration rates, McKenzie and Rapoport (2011) found evidence of lower educational aspirations of Mexican children when parents migrate, as they intended to follow their parents' example and migrate abroad. In China, $\mathrm{Hu}$ (2012) shows that parental migration negatively affects children's school attendance, especially of girls. At the same time, there is research that found neutral effects of migration on children's schooling. In three South-East Asian countries, Jordan and Graham (2012) found no evidence of a direct parental migration effect on children's school enjoyment and performance.

The main implication of parental migration is that children do not live with one or both parents on a daily basis. However, this situation is not specific to transnational families. Because of problematic family circumstances, children with divorced or separated 
parents may also live apart for extended periods of time. Few scholars were able to compare the education of children in transnational care with those in problematic family situations. Comparing separation due to divorce and separation due to migration, Nobles (2011) concluded that ties of Mexican children with migrant fathers are positively correlated with years of completed schooling and with aspirations to attend college. In the same country context, Creighton, Park, and Teruel (2009) found that school dropout rates are higher among children whose fathers either migrated or divorced.

\section{The present research}

The current study asks 'What is the overall relationship between parental absence and the school performance of children who stay behind in Ghana, Nigeria and Angola; and how do different transnational child-raising arrangements in the country of origin relate to the school performance of children in transnational care?' The gap in theoretical understanding of the educational experiences of children in various transnational and non-transnational settings leads us to rely initially on emerging models of educational performance, in particular starting with and extending the models developed by Cortes (2015), and McKenzie and Rapoport (2011). These scholars assume that educational performance of children is mainly the outcome of two inputs: economic and parental resources. The economic input refers, among others, to remittances and any form of resources needed to pay for a child's schooling, school supplies, or to mitigate the need of a working child at home. The parental input denotes the amount and the quality of time parents devote to their children, providing the needed emotional support and giving the overall guidance during the schooling period. However, the effect of having parents away due to migration is likely to affect both the parental and economic inputs into the education of children in transnational care. Therefore, the need to account for specifics in transnational family forms seems central to understanding the educational performance of children who stay behind.

There is limited empirical evidence that compares the effects of national and international migration on educational outcomes of children in the same country context. International migration implies large distances with limited direct interactions between the parent and the child. The literature suggests that parental input is more effective when the distance is shorter and there are fewer administrative barriers for children to meet their migrant parents (Cortes 2015). However, the availability of modern communication technologies may mitigate the effects of distance on child-parent interactions (Schmalzbauer 2004). Recent studies emphasise the positive effects of efficient long-distance communication channels on the well-being of children who stay behind (Wen and Lin 2012). In this study, we also consider international or internal migration that may occur under conditions of divorce or separation of parents in which case children and parents experience both separation from each other but also a certain degree of emotional stress. The context of separation because of marriage termination has an increased potential to negatively affect children in finishing school and their educational aspirations (Nobles 2011).

To take into account the complexity behind parental absence, we distinguish between the locations of the migrant parent, i.e. away internally or internationally, and whether parents are together or separated/divorced. Additionally, we distinguish three different 
transnational family configurations: who the migrant parent is, i.e. children with a migrant mother and living with the father, with a migrant father and living with the mother, with both parents away; the stability of the caregiving arrangements, i.e. the child never changed caregiver or changed it often; and whether the child receives remittances from the migrant parent. Throughout the analysis, we compare children in transnational families with children living in non-migrant households.

Who the migrant parent is, is found by the transnational migration literature to impact the well-being of children who stay behind. Particularly the absence of a mother is largely linked with negative outcomes for children. Notably, however, most studies looking into parental migration do not distinguish between who the caregiver of the child is when one parent is absent. In general, which parent is absent, whether the mother or the father should matter less as long as the parent who stays behind fulfills the parental needs of a child. In the African countries of our study it is often that children with a migrant father are cared for by mothers while children with migrant mothers are mostly under the care of a kin relation, usually grandparents, aunts, uncles or older siblings, who often have families of their own and feel the burden of raising additional children (Mazzucato, Cebotari et al. 2015; Mazzucato and Cebotari 2016). Yet, some studies point to the normative practice of extended family living arrangements that mitigate the transitions for children when parents migrate (Jordan and Graham 2012; Mazzucato, Cebotari et al. 2015; Mazzucato and Cebotari 2016). The effective family norms of child fostering that are prevalent in Africa may provide a buffer from the potential negative effects coming with parental absence on children who stay behind. Furthermore, recent studies on the role of African men in transnational parenting practices, find that fathers are increasingly engaged in the raising of their children, especially when the marital relationship is intact (Carling and Tønnessen 2013; Mazzucato and Cebotari 2016; Poeze 2016).

The role of the caregiver in the life of children who stay behind is conceptually important and needs further investigation. When parents migrate and children stay with a caregiver, they usually need to adapt to new care arrangements, form new attachments and accept new authority figures (Schmalzbauer 2004; Smith, Lalonde and Johnson 2004). The stability of the caregiving arrangements is a feature that is not present in the migration-focused research but it is covered in family studies linked to divorce and separation (Mazzucato and Schans 2011). Commonly, the literature finds negative effects of parental care disruptions due to divorce on children's years of education (Amato and Cheadle 2005). However, these estimates are not directly comparable with the context of this study since parental absence due to migration is likely to differ from parental absence which is accompanied by divorce or separation. Research shows that parental migration and parental divorce produce distinct experiences for children and that children's school aspirations are better when separation is due to migration rather than divorce (Nobles 2011).

Educational performance of children is also sensitive to remittances. Conditional on the earning potential of people who migrate, it was found that African migrants abroad earn and remit more than continental or internal migrants (Mazzucato, Boom and NsowahNuamah 2008). At the same time, studies based on Filipino migrants have found that migrant mothers send, on average, lower remittances and earn less than migrant fathers when working abroad (Cortes 2015). The parental distinction of remitting however 
should matter less because, ceteris paribus, migrant households have more income potential than non-migrant households, hence positively affecting the overall economic input of children of migrants. Studies show that Mexican and Salvadorian children in transnational families who receive remittances from their parents have better grades and are less likely to leave school (Edwards and Ureta 2003; Kandel and Kao 2001; McKenzie and Rapoport 2007). At the same time, scholars found that school performance of Filipina children suffered because remittances could not always compensate for parental absence, especially that of mothers (Cortes 2015). Nevertheless, as long as remittances relax the liquidity constraints of households and channel the cash towards children, than, in theory, it should positively affect children's school performance.

\section{The context of Ghana, Nigeria and Angola}

Ghana, Nigeria and Angola have a long history of migration. People moved internally and across other sub-Saharan countries for the purpose of nomadic livestock keeping, trade and commerce. Cultural and ethnic ties were also important factors dictating migration with neighbouring countries in the region. During British colonial rule, a limited number of Ghanaian and Nigerian students and professionals migrated abroad, especially to the UK. After the independence of Ghana in 1957 and of Nigeria in 1960 and especially during the economic downturn in the late 1970s caused by rising oil prices, both countries experienced economic difficulties that triggered a period of heighted out-migration which continues today. The main Western destinations for Ghanaian and Nigerian migrants are the USA, the UK, Germany, Italy and the Netherlands (Adepoju 2004). Traditionally, men migrate more than women, although the share of migrant women has increased in recent decades, leading to a feminisation of migration in both countries (Pillinger 2007).

Angola became a Portuguese colony in the sixteenth century, and gained its independence from Portugal in 1975. Immediately after that, Angola was ravaged by three decades of civil war (1975-2002). During the conflict, many Angolans migrated from rural to urban areas (urban safety) within the country. Also, many Angolans experienced intraregional and international refugee displacement. A more limited number of Angolans have also migrated abroad as professional labour. The main countries of destination for Angolans were Portugal, Zambia, Namibia, France, Germany, the UK, the Republic of Congo, the Netherlands, Brazil and the USA (Almeida 2010). After the war, Angola experienced peace and economic progress, with many Angolans returning, resettling and reintegrating in Angolan society (IOM 2010).

Family norms in Ghana, Nigeria and Angola are characterised by notions of social parenthood and child fostering, where it is considered appropriate for parents, whether they are migrants or not, to leave their children in the care of people other than the biological parents (Goody 1982). Such norms have facilitated the migration of parents across and beyond the African continent. In all three countries a large proportion of children living without one or both of their biological parents attests to the widespread practice of child fostering. Demographic data show that a significant proportion of Ghanaian and Nigerian children living in urban areas, excluding orphans, and aged $0-14$, do not live with either mother (Ghana, 4.3\%; Nigeria, 5\%), father (Ghana, 22.3\%; Nigeria, $8.7 \%$ ) or both (Ghana, 15.2\%; Nigeria, 7.8\%) (GDHS 2008; NDHS 2008). In Angola, $14 \%$ of children in urban areas, who are under the age of 15 , do not live with at least 
one biological parent (INE 2010). Yet, in Angola, additionally, many children are orphans due to the war (UNHCR 2014).

\section{Method}

\section{The data and sample}

This study is part of a large-scale project measuring the effects of transnational childraising arrangements on life-chances of children, migrant parents and caregivers between Africa and Europe. The analysis for this paper is based on a cross-sectional survey collected among junior and secondary school children in Ghana $(N=2760)$, Nigeria $(N=2168)$ and Angola $(N=2243)$. The data were collected in 2010-2011. In each country the survey was conducted in urban areas with high out-migration profiles. A stratified sampling procedure was employed to randomly select schools in each location. The selection ensured that there are equal numbers of public and private, and high- and low-quality schools. The classification of schools is established by the education offices in each country. In total, 22 schools in Ghana, 27 schools in Angola and 25 schools in Nigeria were surveyed. In each school, a class was randomly selected from each of the three grades. Subsequently, an additional random but purposive sample of children with migrant parents was selected in each school to ensure a sufficient number of children in transnational families. The overall samples are not representative at the national level but protocols were established to allow future replication.

The survey questionnaire contains over 190 indicators measuring socio-economic characteristics, parental migration status and children's education, health and emotional well-being. The questionnaire was administered as a self-reporting tool with students filling the data themselves under the guidance and the supervision of the surveying team. The same version of the questionnaire and the same surveying procedure were applied in all three countries. The sample comprises children and youths aged 11-21 living in both migrant and non-migrant families, where the parental migration status did not changed for a period of at least three months at a time when the survey took place. The age range reflects the distribution of age of students in the surveyed classrooms. In the analysis, the migration status of the parent is considered that of international migration except for the indicator location of the migrant parent (see below) where children with parents away internally were also included in the sample. Children with at least one parent deceased and no parent who migrated (Ghana $N=183$; Angola $N=239$; Nigeria $N=89$ ), those whose parents are married but live in different locations in the same town (Ghana $N=24$; Angola $N=48$; Nigeria $N=12$ ) and those who did not know where their parents were at the time of the survey (Ghana $N=50$; Angola $N=46$; Nigeria $N=32$ ) were omitted from the analysis.

\section{Analysis}

Our data include child-level observations that are nested at the school level. To avoid violating the assumption of independent error terms, we analyse data in a multilevel manner. Hence, we employ two-level mixed-effects linear models to examine the impact of parental absence and of various transnational characteristics on children's school performance. The 
intraclass correlation coefficients are used to check for design effects and assess the fit of the school level dimension in models.

The analysis is conducted in two stages. The first step centres on the analysis of the location of parents who are away-when children live in a transnational or a marriage disrupted family with parents away internally or internationally. This stage of analysis used hierarchical regression modelling (Table 3). Firstly, a basic model was built where child characteristics (age, gender, number of siblings, younger siblings in the house and children's health status) were included. Secondly, indicators measuring the household characteristics were added (education of mother and father, a family process measure and the socio-economic status). The final model additionally controls for school mediating characteristics (distance to school and hours doing homework).

The second step of the analysis incorporates three transnational characteristics-who is the migrant parent and who is the caregiver, the stability of care arrangements and remittances, to assess the various effects of parental migration on children's school performance (Table 4). To fully capture the effects of transnational migration on children's school performance, the models in the second stage of the analysis exclude children with parents away and who are not in a marital relationship.

All measurements were tested for collinearity and none was detected: the variation inflation factors (1-1.5) and the tolerance values (0.8-0.9) were average.

\section{Measures}

The main measurements in this analysis account for the parental location, which migrant parent is absent and who is the caregiver, the stability of caregiving arrangements and remittances. Table 2 displays the descriptive characteristics of these measurements in relation to children's school performance. Other independent factors include characteristics of the child and parents, a family process measure, living conditions and school mediating indicators (Table 1).

The dependent variable is an indexed measure of children's average grades in science, language and mathematics. In the three African countries in focus in this study, these are the main courses taught consistently in both junior and secondary schools. The language scores in Ghana and Nigeria are those of English while in Angola are those of Portuguese. The science scores in Angola are those of history. The index averaging grades range from 0 to 100 in Ghana and Nigeria and from 0 to 20 in Angola, with higher values pointing to better school results. A similar way of assessing educational performance has been employed by scholars in other country contexts. Specifically, Altschul (2012) measured school performance of Mexican American pupils by averaging grades in four major subjects: reading, math, science and history. Similarly, Kandel and Kao (2001) measured school performance of Mexican children by considering the overall standardised grades received by pupils in all subjects during the academic year. Averaging grades of the main courses taught in schools has the advantage of producing a consolidated measure that captures the school performance in its complexity.

The survey contains rich information regarding the transnational life of children. The location of the migrant parent captures the dimension of parental absence-whether parents are away internally or internationally due to migration, or are away internally or internationally but are divorced/separated. We further use an indicator measuring 
Table 1. Means/percentages of variables in the sample per country.

\begin{tabular}{|c|c|c|c|c|c|c|}
\hline & \multicolumn{2}{|l|}{ Ghana } & \multicolumn{2}{|l|}{ Nigeria } & \multicolumn{2}{|l|}{ Angola } \\
\hline & $\begin{array}{l}\text { Percentage/mean } \\
\text { (SD) }\end{array}$ & $N / n$ & $\begin{array}{l}\text { Percentage/mean } \\
\text { (SD) }\end{array}$ & $N / n$ & $\begin{array}{l}\text { Percentage/mean } \\
\text { (SD) }\end{array}$ & $N / n$ \\
\hline Educational performance & $67.6(12.9)$ & 2275 & $60.3(16.7)$ & 1567 & $12.3(2.3)$ & 2016 \\
\hline Location parent(s) and marital status & & 2420 & & 2040 & & 1905 \\
\hline Non-migrant parents & 46.9 & 1135 & 64.8 & 1321 & 49.5 & 943 \\
\hline $\begin{array}{l}\text { Parent(s) away internally: } \\
\text { together }\end{array}$ & 15.5 & 375 & 11.7 & 238 & 14.1 & 269 \\
\hline $\begin{array}{l}\text { Parent(s) away internationally: } \\
\text { together }\end{array}$ & 15.9 & 385 & 11.8 & 241 & 5.7 & 109 \\
\hline $\begin{array}{l}\text { Parents(s) away internally: } \\
\text { divorced/separated }\end{array}$ & 15.3 & 371 & 9.2 & 187 & 22.4 & 427 \\
\hline $\begin{array}{l}\text { Parents(s) away internationally: } \\
\text { divorced/separated }\end{array}$ & 6.4 & 154 & 2.6 & 53 & 8.2 & 157 \\
\hline $\begin{array}{l}\text { Who is the migrant parent and who } \\
\text { is the caregiver }\end{array}$ & & 1587 & & 1563 & & 1079 \\
\hline Living with both parents & 74.3 & 1179 & 84.6 & 1323 & 88.8 & 958 \\
\hline Father abroad, mother caregiver & 14.5 & 230 & 9.2 & 144 & 6.6 & 71 \\
\hline Mother abroad, father caregiver & 3.0 & 48 & 2.1 & 32 & 1.5 & 16 \\
\hline $\begin{array}{l}\text { Both parents away, other } \\
\text { caregiver }\end{array}$ & 8.2 & 130 & 4.1 & 64 & 3.1 & 34 \\
\hline Stability of the care arrangement & & 1349 & & 1496 & & 922 \\
\hline $\begin{array}{l}\text { Non-migrant parents: changed } \\
\text { never }\end{array}$ & 58.0 & 783 & 69.4 & 1038 & 70.3 & 648 \\
\hline $\begin{array}{l}\text { Non-migrant parents: changed } \\
\text { caregiver } \geq 1\end{array}$ & 17.4 & 234 & 16.0 & 239 & 19.5 & 180 \\
\hline $\begin{array}{l}\text { Parent } \overline{a w a y} \text { : never changed } \\
\text { caregiver }\end{array}$ & 13.1 & 177 & 7.3 & 110 & 6.0 & 55 \\
\hline $\begin{aligned} & \text { Parent away: changed caregiver } \\
\geq & 1\end{aligned}$ & 11.5 & 155 & 7.3 & 109 & 4.2 & 39 \\
\hline$\overline{\text { Receiving remittances }}$ & & 1323 & & 1945 & & 1672 \\
\hline Non-migrant parents & 85.8 & 1135 & 70.8 & 1377 & 58.5 & 978 \\
\hline Parent away: yes remittances & 11.4 & 151 & 21.0 & 408 & 21.3 & 356 \\
\hline Parent away: no remittances & 2.8 & 37 & 8.2 & 160 & 20.2 & 338 \\
\hline Child age & & 2758 & & 2162 & & 2238 \\
\hline $11-14$ years & 29.8 & 822 & 61.1 & 1322 & 30.6 & 686 \\
\hline $15-17$ years & 49.6 & 1369 & 34.6 & 747 & 39.9 & 892 \\
\hline $18-21$ years & 20.6 & 567 & 4.3 & 93 & 29.5 & 660 \\
\hline Child is girl & 53.4 & 1474 & 55.2 & 1196 & 54.1 & 1213 \\
\hline $\begin{array}{l}\text { The child is living with younger } \\
\text { siblings }\end{array}$ & 57.3 & 1557 & 54.8 & 1173 & 78.0 & 1710 \\
\hline $\begin{array}{l}\text { Number of siblings living with the } \\
\text { child }\end{array}$ & $3.1(2.4)$ & 2760 & $2.9(2.2)$ & 2168 & $3.8(2.8)$ & 2243 \\
\hline Child is healthy & 45.2 & 1212 & 60.8 & 1305 & 19.5 & 417 \\
\hline $\begin{array}{l}\text { Mother's education secondary or } \\
\text { more }\end{array}$ & 42.5 & 1108 & 76.8 & 1613 & 36.4 & 763 \\
\hline $\begin{array}{l}\text { Father's education secondary or } \\
\text { more }\end{array}$ & 60.6 & 1584 & 80.5 & 1688 & 50.2 & 1043 \\
\hline $\begin{array}{l}\text { Good relationship with the parents/ } \\
\text { caregiver }\end{array}$ & 63.5 & 1602 & 63.6 & 1319 & 43.3 & 873 \\
\hline Living conditions are better & 57.8 & 1574 & 63.6 & 1319 & 24.8 & 535 \\
\hline $\begin{array}{l}\text { Number of people per rooms in the } \\
\text { house }\end{array}$ & $1.6(2.2)$ & 2490 & $1.1(1.0)$ & 2074 & $1.6(1.1)$ & 1987 \\
\hline Time-distance from home to school & $3.0(1.7)$ & 2710 & $3.0(1.5)$ & 2146 & $3.6(1.4)$ & 2144 \\
\hline Number of hours doing homework & $2.8(1.5)$ & 2684 & $3.0(1.6)$ & 2141 & $2.2(1.2)$ & 2097 \\
\hline
\end{tabular}

Notes: Standard deviations in parentheses.

which migrant parent is absent-migrant mother is away and the child lives with the father, migrant father is away and the child lives with the mother, and both parents are away. Another indicator accounts for the stability of the care arrangement-children live with both parents and never changed caregiver, children live with both parents and 
changed caregiver at least once, children have at least one parent abroad and never changed caregiver, and children have at least one parent abroad and changed caregiver at least once. Finally, a measure is employed to look if children in transnational families receive remittances or not.

Five variables relating to characteristics of children were derived. Age was recorded as full years and then recoded in three categories: younger children (11-14), adolescents (1517) and older children (18-21). Gender of the child was included where 1 denotes girls. The total number of siblings and the presence of younger siblings living with the child have been also considered. In the African countries in focus in this study, it is common for children of different parents to live in the care of a caregiver. Therefore, the information pertaining to siblings refers to biological brothers and sisters, as well as half brothers and sisters, and those children in foster care who live under the same roof with the surveyed child. Finally, a binary indicator of children's health status was included in the analysis. This indicator was created from responses to the question 'On a scale from 1 [not good] to 5 [very good], how would you rate your own health?' Children indicating health values of four and five were assigned a good health. Previous research notes that children reporting better health are more likely to have increased educational performance (Kong and Meng 2010).

Parental characteristics, in particular maternal education, can impact the educational performance of children (Altschul 2012; Hu 2012). We include binary indicators measuring maternal and paternal education by comparing parents who have completed upper secondary or higher education with those with lower secondary education or less.

We include one family process measure to account for the quality of the family functioning (Jordan and Graham 2012). The questionnaire version of the question asks 'Overall, how would you characterise your relationship with your mother/father/caregiver?' There are five response categories (always open/warm, often open/warm, sometimes open/warm, hardly ever open/warm and never open/warm), which are split to create a binary indicator where 1 indicates that children have always/often a good quality relationship with their parents or caregivers. Previous studies found that a positive family process is likely to increase the educational performance of children (Jordan and Graham 2012).

Additionally, two measures summarise the living conditions of children. The first indicator looks at children's living conditions compared to others. This indicator was operationalised from the following question 'Compared to other children, would you say that your living conditions are better, the same, or less good?' For the analysis, this measurement was coded as binary where 1 indicates better living conditions and 0 otherwise. The second indicator is a measure of the housing quality. It was constructed by dividing the total number of people living in the house by the total number of rooms used for living in the house. Previous research shows that there is a positive relationship between good living conditions and better school achievements among children (Altschul 2012).

Finally, two school mediating indicators were included in the analysis. One measure accounts for the time-distance from home to school, a factor which was found to increase the cost of school attendance (Edwards and Ureta 2003). This indicator is employed as continuous and comprises the following categories: 0 minutes (live in boarding school); 
1-14 minutes; 15-29 minutes; 30-44 minutes; 45-59 minutes; 60 and more minutes. The second measure records the number of hours the child spends doing homework every day. Research shows a positive relationship between the time children spend doing homework and better outcomes in school (Altschul 2012).

\section{Results}

\section{Descriptive results}

Table 1 presents descriptive statistics of the dependent and independent variables. The proportion of parents who are away internally and internationally due to migration is larger in Ghana and smaller in Angola and Nigeria. At the same time, Angola has a higher proportion of parents who are away internally or internationally and are divorced/separated. When parents migrate, it is usually the father who goes abroad and children stay in the care of the mother. In Angola and Nigeria, children in transnational care changed caregivers less often compared to Ghanaian children. Similarly, the proportion of children who receive remittances is higher in Nigeria and Angola compared to Ghana. On average, children in our sample are younger (11-14 years old) in Nigeria and older (15-17 years old) in Ghana and Angola. There is a balanced proportion of boys and girls in the data. Children in Angola live with more siblings at home, report worsened health, have a more problematic relationship with their parents and caregivers, have poorer living conditions, spend more time reaching schools and do less homework compared to children in Ghana and Nigeria.

Table 2 presents the five transnational characteristics in relation to children's school performance. On average, children with parents away internationally and in a stable marital relationship show no differing performance in schools than children with parents away internationally and in strained marital relationship. When looking at specifics of parental migration, data show that children with both parents away have a lower performance in school compared to children with a parent away while the other parent is the caregiver. A stable care arrangement has a slightly positive influence on grades of children in transnational care. Finally, results show that children in transnational care who receive remittances have improved grades in school compared to children in transnational care who do not receive remittances.

\section{Regression results}

One concern addressed by this study is that educational performance of children may vary when considering the marital status of the migrant parent (Table 3). Results show differing patterns across countries. In Ghana, there is a negative association between international parental migration and children's education (Models 2-3, Table 3). In Nigeria, children's performance in school is likely to decrease when parents migrate internally and are in a strained marital relationship (Models 4-6, Table 3). In Angola, children in migrant families, with divorced or married parents, have no differing performance in school than children in non-migrant families.

The hierarchical models in Table 3 show significant changes in coefficients related to parental migration and marital status in two specific instances: (1) in Ghana, the inclusion 
Table 2. Means (standard deviations) of educational performance by transnational family characteristics.

\begin{tabular}{|c|c|c|c|c|c|c|c|c|c|}
\hline \multirow{3}{*}{ Transnational family characteristic } & \multicolumn{9}{|c|}{ Educational performance $^{a}$} \\
\hline & \multirow[t]{2}{*}{$N / n$} & \multicolumn{2}{|c|}{ Ghana } & \multirow[t]{2}{*}{$N / n$} & \multicolumn{2}{|c|}{ Nigeria } & \multirow[t]{2}{*}{$N / n$} & \multicolumn{2}{|c|}{ Angola } \\
\hline & & & & & & & & & \\
\hline Location parent(s) and marital status & \multicolumn{3}{|c|}{$F(4,1979)=12.41^{* * *}$} & \multicolumn{3}{|c|}{$F(4,1465)=11.77^{* * *}$} & \multicolumn{3}{|c|}{$F(4,1713)=1.20$} \\
\hline Non-migrant parents & 921 & 69.01 & $(13.00)$ & 955 & 61.75 & $(15.80)$ & 847 & 12.40 & (2.36) \\
\hline Parent(s) away internally: together & 311 & 65.60 & $(13.44)$ & 169 & 55.38 & $(18.71)$ & 245 & 12.01 & $(2.26)$ \\
\hline Parent(s) away internationally: together & 317 & 69.01 & (12.75) & 168 & 63.14 & (18.01) & 103 & 12.42 & (1.84) \\
\hline Parents(s) away internally: divorced/separated & 311 & 64.01 & $(12.70)$ & 144 & 54.19 & $(17.50)$ & 378 & 12.41 & $(2.26)$ \\
\hline $\begin{array}{l}\text { Parents(s) away internationally: divorced/ } \\
\text { separated }\end{array}$ & 124 & 69.79 & $(11.27)$ & 34 & 60.89 & $(10.54)$ & 145 & 12.38 & $(2.37)$ \\
\hline$N$ & \multicolumn{3}{|l|}{1984} & \multicolumn{3}{|l|}{1470} & \multicolumn{3}{|l|}{1718} \\
\hline $\begin{array}{l}\text { Who is the migrant parent and who is the } \\
\text { caregiver }\end{array}$ & \multicolumn{3}{|c|}{$F(3,1292)=1.64$} & \multicolumn{3}{|c|}{$F(3,1118)=2.82^{*}$} & \multicolumn{3}{|c|}{$F(3,969)=0.13$} \\
\hline Non-migrant parents & 959 & 69.19 & $(12.98)$ & 957 & 61.77 & $(15.79)$ & 861 & 12.39 & (2.36) \\
\hline Father away, mother caregiver & 194 & 69.64 & $(11.42)$ & 100 & 65.87 & $(15.42)$ & 68 & 12.33 & (1.71) \\
\hline Mother away, father caregiver & 39 & 70.12 & $(12.79)$ & 19 & 61.10 & (19.44) & 16 & 12.64 & $(1.51)$ \\
\hline Both parents away, other caregiver & 104 & 66.48 & $(14.28)$ & 46 & 58.37 & $(19.81)$ & 28 & 12.12 & $(2.30)$ \\
\hline$N$ & 1296 & & & 1122 & & & 973 & & \\
\hline Stability of the care arrangement & \multicolumn{3}{|c|}{$F(3,1105)=0.37$} & \multicolumn{3}{|c|}{$F(3,1071)=1.58$} & \multicolumn{3}{|c|}{$F(3,830)=0.03$} \\
\hline Non-migrant parents: changed never & 635 & 68.84 & $(13.26)$ & 751 & 62.01 & $(15.46)$ & 577 & 12.44 & (2.33) \\
\hline Non-migrant parents: changed caregiver $\geq 1$ & 198 & 69.08 & $(13.02)$ & 171 & 60.87 & $(16.76)$ & 167 & 12.41 & $(2.39)$ \\
\hline Parent away: never changed caregiver & 150 & 70.05 & $(11.66)$ & 77 & 61.91 & $(19.53)$ & 52 & 12.52 & $(1.85)$ \\
\hline Parent away: changed caregiver $\geq 1$ & 126 & 68.74 & $(13.71)$ & 76 & 65.64 & (15.57) & 38 & 12.41 & (1.34) \\
\hline$N$ & 1109 & & & 1075 & & & 834 & & \\
\hline Receiving remittances & \multicolumn{3}{|c|}{$F(2,1074)=2.81$} & \multicolumn{3}{|c|}{$F(2,1392)=2.37$} & \multicolumn{3}{|c|}{$F(2,1509)=0.19$} \\
\hline Non-migrant parents & 921 & 69.08 & $(13.02)$ & 996 & 61.37 & $(15.87)$ & 877 & 12.39 & (2.36) \\
\hline Parent away: yes remittances & 127 & 68.41 & $(12.41)$ & 293 & 60.38 & $(17.68)$ & 327 & 12.44 & $(2.29)$ \\
\hline Parent away: no remittances & 29 & 63.40 & $(10.73)$ & 106 & 57.87 & (16.88) & 308 & 12.33 & (2.18) \\
\hline$N$ & 1077 & & & 1395 & & & 1512 & & \\
\hline
\end{tabular}

Notes: Analysis of variance was used for all comparisons. Except for the location of parent(s) and marital status, the samples exclude those children with parents divorced/separated, those with parents away internally, those with parents deceased, those who could not indicate where their parents were located and those whose parents are married but live in different locations in the same town.

${ }^{a}$ Educational performance values range from 0 to 100 in Ghana and Nigeria and from 0 to 20 in Angola.

${ }^{*} p<.05$.

${ }^{* *} p<.01$.

$* * * 0.001$.

of parental, family and schooling indicators renders the coefficients for internal migration when parents are divorced/separated insignificant and (2) in Nigeria and Angola, the inclusion of subsequent clusters of indicators makes the results insignificant for when parents are away internally and in a stable marital relationship. Therefore, we conclude that parental, family and schooling conditions mediate the negative effects on education of internal migration when parents are in a strained marital relationship in Ghana and when parents are together in Nigeria and Angola.

The second part of the analysis focuses on international parental migration by considering different transnational child-raising arrangements and how they relate with children's school performance. To account for the sole effect of international parental migration, this stage of analysis omits children whose parents are divorced/separated. Table 4 presents three sets of models, each of which assesses the effects of a different transnational characteristic on educational performance of children in each country. When using the first transnational characteristic of who the migrant parent is (Models 10, 13 
Table 3. Educational performance, the location and the marital status of the migrant parents.

\begin{tabular}{|c|c|c|c|c|c|c|c|c|c|c|c|c|c|c|c|c|c|c|}
\hline & \multicolumn{6}{|c|}{ Ghana } & \multicolumn{6}{|c|}{ Nigeria } & \multicolumn{6}{|c|}{ Angola } \\
\hline & \multicolumn{2}{|c|}{ Model 1} & \multicolumn{2}{|c|}{ Model 2} & \multicolumn{2}{|c|}{ Model 3} & \multicolumn{2}{|c|}{ Model 4} & \multicolumn{2}{|c|}{ Model 5} & \multicolumn{2}{|c|}{ Model 6} & \multicolumn{2}{|c|}{ Model 7} & \multicolumn{2}{|c|}{ Model 8} & \multicolumn{2}{|c|}{ Model 9} \\
\hline & $\beta$ & SE & $\beta$ & SE & $\beta$ & SE & $\beta$ & SE & $\beta$ & SE & $\beta$ & SE & $\beta$ & SE & $\beta$ & SE & $\beta$ & SE \\
\hline \multicolumn{19}{|c|}{$\begin{array}{l}\text { Location parent(s) and marital status } \\
\text { Non-migrant parents }\end{array}$} \\
\hline $\begin{array}{l}\text { Non-migrant pare } \\
\text { Parent(s) away } \\
\text { internally: together }\end{array}$ & $s$ & $(0.77)$ & -1.26 & $(0.86)$ & -1.19 & $(0.86)$ & $-3.84^{* *}$ & $(1.32)$ & -2.76 & (1.46) & -2.85 & (1.46) & $0.40^{*}$ & $(0.17)$ & -0.36 & $(0.20)$ & -0.27 & $(0.20)$ \\
\hline $\begin{array}{l}\text { Parent(s) away } \\
\text { internationally: } \\
\text { together }\end{array}$ & -1.18 & $(0.74)$ & $-2.06^{*}$ & $(0.83)$ & $-1.96^{*}$ & $(0.83)$ & -2.87 & $(1.47)$ & -2.87 & (1.58) & -2.47 & (1.57) & -0.41 & $(0.29)$ & -0.49 & $(0.32)$ & -0.47 & $(0.32)$ \\
\hline $\begin{array}{l}\text { Parents(s) away } \\
\text { internally: divorced/ }\end{array}$ & $-1.51^{*}$ & $(0.77)$ & -1.06 & $(0.86)$ & -0.98 & $(0.86)$ & $-4.83^{* * *}$ & $(1.42)$ & $-5.42^{* * *}$ & $(1.56)$ & $-5.55^{* * *}$ & $(1.56)$ & -0.10 & $(0.14)$ & -0.06 & (0.15) & 0.02 & $(0.16)$ \\
\hline $\begin{array}{l}\text { Parents(s) away } \\
\text { internationally: } \\
\text { divorced/separated }\end{array}$ & 0.51 & $(1.09)$ & 0.27 & $(1.21)$ & 0.77 & $(1.22)$ & -3.93 & $(2.82)$ & -1.33 & $(3.05)$ & -1.50 & (3.09) & -0.38 & $(0.25)$ & -0.35 & $(0.27)$ & -0.31 & $(0.27)$ \\
\hline \multicolumn{19}{|l|}{ Child age } \\
\hline $15-17$ & 0.61 & $(0.73)$ & 1.11 & $(0.84)$ & 0.87 & $(0.84)$ & $-2.46^{* *}$ & $(0.94)$ & $-2.37^{*}$ & $(1.00)$ & $-2.64^{* *}$ & $(1.01)$ & -0.28 & $(0.15)$ & -0.24 & $(0.17)$ & -0.25 & $(0.17)$ \\
\hline $18-21 y$ & -1.53 & (1.03) & -0.63 & $(1.17)$ & -0.95 & (1.17) & -3.61 & (2.18) & -2.47 & (2.41) & -3.05 & (2.46) & $-0.87^{* * *}$ & $(0.18)$ & $-0.83^{* * *}$ & $(0.20)$ & $-0.87^{* * *}$ & $(0.21)$ \\
\hline Child is $c$ & $-3.55^{* * *}$ & $(0.55)$ & $-4.01 * * *$ & $(0.62)$ & $-4.05^{* * *}$ & $(0.62)$ & $-2.30^{* *}$ & $(0.85)$ & $-2.55^{* *}$ & $(0.92)$ & $-2.63^{* *}$ & $(0.93)$ & -0.11 & $(0.11)$ & -0.07 & $(0.12)$ & -0.07 & $(0.12)$ \\
\hline $\begin{array}{l}\text { The child is living } \\
\text { with younger } \\
\text { siblings }\end{array}$ & 0.23 & $(0.55)$ & 0.54 & $(0.62)$ & 0.51 & $(0.62)$ & -0.99 & $(0.86)$ & -0.69 & $(0.92)$ & -0.65 & $(0.92)$ & 0.05 & $(0.13)$ & 0.01 & $(0.15)$ & 0.04 & $(0.15)$ \\
\hline $\begin{array}{l}\text { Number of siblings } \\
\text { living with the child }\end{array}$ & -0.06 & $(0.11)$ & -0.08 & $(0.13)$ & -0.06 & $(0.13)$ & -0.10 & $(0.20)$ & -0.12 & $(0.21)$ & -0.11 & $(0.21)$ & $-0.06^{* *}$ & $(0.02)$ & $-0.06^{* *}$ & $(0.02)$ & $-0.07^{* *}$ & $(0.02)$ \\
\hline Child is healthy & $1.08^{*}$ & $(0.52)$ & 0.89 & $(0.58)$ & 0.76 & $(0.58)$ & 1.21 & $(0.83)$ & 1.19 & $(0.90)$ & 1.10 & $(0.90)$ & -0.05 & $(0.13)$ & -0.06 & $(0.15)$ & -0.14 & $(0.15)$ \\
\hline $\begin{array}{l}\text { Mother's education } \\
\text { secondary or more }\end{array}$ & & & $3.57^{* * *}$ & $(0.6$ & $3.34^{* * *}$ & $(0.69)$ & & & $3.94^{* *}$ & $(1.3$ & $3.86^{* *}$ & (1.32) & & & 0.27 & $(0.14)$ & 0.23 & $(0.14)$ \\
\hline Father's education & & & 0.68 & $(0.66)$ & 0.45 & $(0.66)$ & & & -0.15 & (1.45) & -0.72 & (1.46) & & & 0.14 & $(0.13)$ & 0.14 & $(0.14)$ \\
\hline $\begin{array}{l}\text { Good relationship } \\
\text { with the parents/ } \\
\text { caregiver }\end{array}$ & & & 1.03 & $(0.61)$ & 0.81 & $(0.61)$ & & & 0.14 & $(0.92)$ & 0.16 & $(0.92)$ & & & 0.08 & $(0.12)$ & 0.08 & $(0.13)$ \\
\hline Living conditions are & & & 0.93 & $(0.60)$ & 0.87 & $(0.60)$ & & & 0.49 & $(0.95)$ & 0.33 & $(0.96)$ & & & 0.11 & $(0.14)$ & 0.09 & $(0.14)$ \\
\hline
\end{tabular}




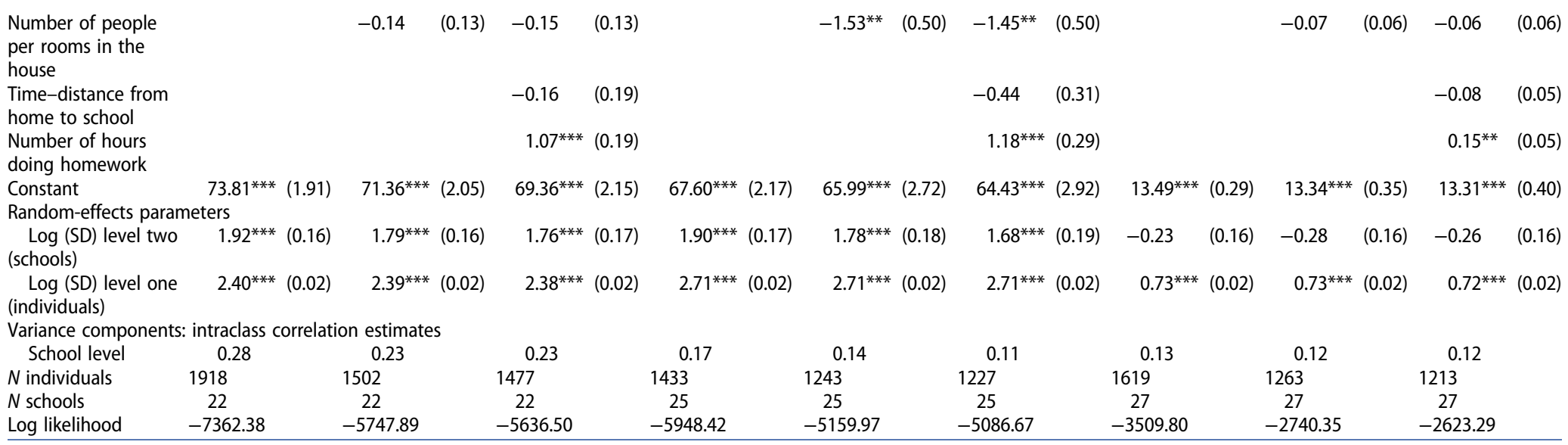

Notes: Standard errors in parentheses. The samples exclude those children who are orphans, those who could not indicate where their parents were located and those whose parents are married but live in different locations in the same town.

${ }^{*} p<.05$.

${ }^{* *} p<.01$.

$* * * p<.00$. 
Table 4. International parental migration and educational performance of children in different transnational care arrangements.

able 4. International parental migration and educational performance of children in different transnational care arrangements.

Angola $^{\mathrm{a}}$

\begin{tabular}{|c|c|c|c|c|c|c|c|c|c|c|c|c|c|c|c|c|c|}
\hline \multicolumn{6}{|c|}{ Ghana $^{a}$} & \multicolumn{6}{|c|}{ Nigeria $^{\circ}$} & \multicolumn{6}{|c|}{ Angola ${ }^{\circ}$} \\
\hline \multicolumn{2}{|c|}{ Model 10} & \multicolumn{2}{|c|}{ Model 11} & \multicolumn{2}{|c|}{ Model 12} & \multicolumn{2}{|c|}{ Model 13} & \multicolumn{2}{|c|}{ Model 14} & \multicolumn{2}{|c|}{ Model 15} & \multicolumn{2}{|c|}{ Model 16} & \multicolumn{2}{|c|}{ Model 17} & \multicolumn{2}{|c|}{ Model 18} \\
\hline$\beta$ & SE & $\beta$ & SE & $\beta$ & SE & $\beta$ & SE & $\beta$ & SE & $\beta$ & SE & $\beta$ & SE & $\beta$ & SE & $\beta$ & SE \\
\hline
\end{tabular}

Who is the migrant parent and who is the caregiver

Living with both parents
Father abroad, mother $\quad-1.80 \quad$ (1.01)

caregiver

$-1.80 \quad(1.01)$

$\begin{array}{rr}1.00 & (1.87) \\ -5.52 & (4.06) \\ -5.97^{*} & (2.58)\end{array}$

$\begin{array}{cc}-0.45 & (0.42) \\ -0.36 & (0.75) \\ 0.11 & (0.62)\end{array}$

Both parents away, other $-3.76^{* *}$ (1.38)

$(0.62)$

Stability of the care arrangement

Non-migrant parents: changed never

Non-migrant parents:

changed caregiver $>1$

$1.34 \quad(1.05)$

$0.18 \quad(1.39)$

$-0.10 \quad(0.23)$

Parent away: never

$-2.16 \quad(1.12)$

$-3.34 \quad(2.11)$

$-0.18 \quad(0.46)$

changed caregiver

$-1.05 \quad(1.23)$

$0.48 \quad(2.10)$

$-0.49 \quad(0.48)$

caregiver $\geq 1$

Remittances

Non-migrant parents: no remittances

Parents away: yes

remittances

Parents away: no remittances

Child age

11-14 years

15-17 years

18-21 years

Child is girl

The child is living with

younger siblings

Number of siblings living with

the child

Child is healthy

Mother's education

secondary or more

$\begin{array}{llll}-1.94 & (1.25) & -1.17 & (1.18) \\ -3.00 & (2.70) & -2.88 & (1.73)\end{array}$

$\begin{array}{ccc}0.06 & (1.4 \\ -3.73^{* * *} & (0.77 \\ 0.04 & (0.7 & \end{array}$

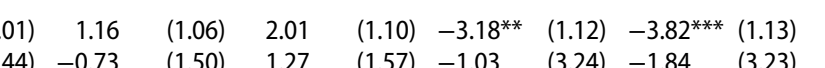

$280^{* *}(1.00)$

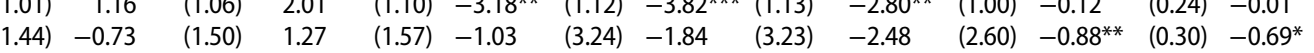

\begin{tabular}{llllllllllll}
$3.73^{* * *}(0.77)$ & $-3.51^{* * *}(0.81)$ & $-4.12^{* * *}(0.85)$ & $-2.47^{*}$ & $(1.03)$ & $-2.54^{*}$ & $(1.04)$ & $-2.84^{* *}$ & $(0.93)$ & -0.16 & $(0.18)$ & -0.05 \\
\hline
\end{tabular}

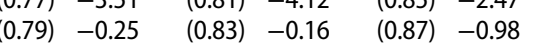

(1.04) -0.64

$\begin{array}{lll}(1.06) & -0.63 \quad(0.93) & -0.01\end{array}$

(0.23) 0.05

$(0.25)$

$(0.19)-0.11$ (0.22)

$\begin{array}{lll}(0.23) & 0.04 & (0.17)\end{array}$

$\begin{array}{llll}0.28 & (0.73) & 0.46 & (0.77) \\ 3.28^{* * *} & (0.84) & 3.43^{* * *} & (0.89)\end{array}$

$\begin{array}{llllll}0.03 & (0.19) & 0.02 & (0.25) & -0.10 & (0.26)\end{array}$

$0.06 \quad(0.22)-0.06$

(0.04) $\quad-0.07$

$(0.04)-0.08^{* *}(0.03)$

$\begin{array}{llllll}0.39 & (0.80) & 1.51 & (0.99) & 1.65 & (1.01) \\ 3.00^{* *} & (0.92) & 3.24^{*} & (1.62) & 2.86 & (1.64)\end{array}$

$\begin{array}{llr}0.78 & (0.90) & -0.05 \\ 3.53 * * & (1.34) & 0.22\end{array}$

(0.22) $\quad 0.08$

$\begin{array}{lll}(0.22) & -0.12 \quad(0.17)\end{array}$

$(0.84)$ 


\begin{tabular}{|c|c|c|c|c|c|c|c|c|c|c|c|c|c|c|c|c|c|c|}
\hline $\begin{array}{l}\text { Father's education secondary } \\
\text { or more }\end{array}$ & 0.62 & $(0.86)$ & 0.58 & $(0.91)$ & 0.95 & $(0.93)$ & -0.73 & $(1.80)$ & -0.97 & $(1.84)$ & 0.11 & $(1.48)$ & 0.17 & $(0.21)$ & 0.27 & $(0.21)$ & 0.09 & $(0.15)$ \\
\hline $\begin{array}{l}\text { Good relationship with the } \\
\text { parents/caregiver }\end{array}$ & 1.48 & $(0.78)$ & $1.78^{*}$ & $(0.82)$ & 1.09 & $(0.85)$ & -0.62 & $(1.03)$ & -0.46 & $(1.05)$ & -0.22 & $(0.92)$ & 0.21 & $(0.19)$ & 0.31 & $(0.19)$ & 0.04 & $(0.14)$ \\
\hline Living conditions are better & $1.81^{*}$ & $(0.76)$ & $2.17^{* *}$ & $(0.81)$ & 1.59 & $(0.84)$ & 0.62 & $(1.09)$ & 0.84 & $(1.11)$ & 0.40 & $(0.98)$ & -0.02 & $(0.20)$ & -0.05 & $(0.20)$ & 0.06 & $(0.15)$ \\
\hline $\begin{array}{l}\text { Number of people per rooms } \\
\text { in the house }\end{array}$ & -0.21 & $(0.19)$ & -0.22 & $(0.20)$ & -0.31 & $(0.20)$ & -1.07 & $(0.62)$ & -1.18 & $(0.63)$ & $-1.62^{* *}$ & $(0.51)$ & 8 & $(0.09)$ & 7 & $(0.09)$ & -0.05 & $.07)$ \\
\hline $\begin{array}{l}\text { Time-distance from home to } \\
\text { school }\end{array}$ & $-0.48^{*}$ & $(0.24)$ & $-0.52^{*}$ & $(0.25)$ & -0.47 & $(0.27)$ & -0.50 & $(0.34)$ & -0.46 & $(0.34)$ & -0.50 & $(0.31)$ & $-0.15^{*}$ & $(0.07)$ & $-0.19^{* *}$ & $(0.07)$ & -0.10 & $(0.05)$ \\
\hline $\begin{array}{l}\text { Number of hours doing } \\
\text { homework }\end{array}$ & $1.31^{* * *}$ & $(0.24)$ & $1.26^{* * *}$ & $(0.25)$ & $1.30^{* * *}$ & $(0.27)$ & $1.66^{* * *}$ & $(0.32)$ & $1.66^{* * *}$ & $(0.33)$ & $1.29 * * *$ & $(0.29)$ & 0.13 & $(0.08)$ & 0.14 & $(0.08)$ & $0.16^{* *}$ & $(0.06)$ \\
\hline Const & $68.63^{* * *}$ & $(2.44)$ & $67.54^{* * *}$ & $(2.55)$ & $68.40^{* * *}$ & $(2.67)$ & $62.72^{* * *}$ & $(3.22)$ & $63.54^{* * *}$ & (3.28) & $63.80^{* * *}$ & $(2.89)$ & $13.59^{* * *}$ & $(0.54)$ & $13.35^{* * *}$ & $(0.54)$ & $13.47^{* * *}$ & $(0.42)$ \\
\hline 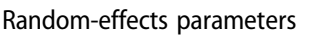 & & & & & & & & & & & & & & & & & & \\
\hline $\begin{array}{l}\text { Log (SD) level two } \\
\text { chools) }\end{array}$ & $1.70^{* * *}$ & $(0.18)$ & $1.70^{* * *}$ & $(0.18)$ & $1.71^{* * *}$ & $(0.18)$ & $1.61^{* * *}$ & $(0.21)$ & $1.57^{* * *}$ & $(0.21)$ & $1.68^{* * *}$ & $(0.19)$ & $-0.41^{*}$ & $(0.20)$ & $-0.38^{*}$ & $(0.19)$ & -0.26 & $(0.17)$ \\
\hline Log (SD) level one & $2.37^{* * *}$ & $(0.02)$ & $2.37^{* * *}$ & $(0.02)$ & $2.37^{* * *}$ & $(0.03)$ & $2.68^{* * *}$ & $(0.02)$ & $2.68^{* * *}$ & $(0.02)$ & $2.69^{* * * *}$ & $(0.02)$ & $0.78^{* * *}$ & $(0.03)$ & $0.76^{* * *}$ & $(0.03)$ & $0.74^{* * *}$ & $(0.02)$ \\
\hline
\end{tabular}

(individuals)

Variance components: intraclass correlation estimates

School level

\begin{tabular}{|c|c|c|c|c|c|c|c|c|c|}
\hline School level & 0.21 & 0.21 & 0.21 & 0.11 & 0.10 & 0.12 & 0.09 & 0.09 & 0.12 \\
\hline$N$ individuals & 933 & 858 & 779 & 945 & 916 & 1167 & 650 & 621 & 1078 \\
\hline$N$ schools & 22 & 22 & 22 & 25 & 25 & 25 & 27 & 27 & 27 \\
\hline Log likelihood & -3559.93 & -3279.40 & -2976.13 & -3895.11 & -3772.21 & -4815.71 & -1441.86 & -1370.73 & -2354.29 \\
\hline
\end{tabular}

Note: Standard errors in parentheses.

${ }^{\text {a }}$ The samples exclude children with parents divorced/separated, those with parents away internally, those who are orphans, those who could not indicate where their parents were located and those whose parents are married but live in different locations in the same town.

${ }^{*} p<.05$.

${ }^{* *} p<.01$.

${ }^{* * *} p<.00$. 
and 16, Table 4) there are no significant effects of either maternal or paternal migration on educational performance of children. In Ghana and Nigeria, the school performance of children with both parents away is negatively affected when compared to children in non-migrant families.

Interactions (not shown) were fitted to test the mediating effect of the relation between who the migrant parent is and the quality of the child-parent/caregiver relationship. We found no significant effects for the interaction terms, meaning that the relations between the quality of the child-parent/caregiver relationship and whether mother, father or both parents migrate do not mediate the educational performance of children in transnational care.

Models 11, 14 and 17 (Table 4) look at the stability of the care arrangements in relation to children's school performance. The results show that changing caregiver does not necessarily result in worse educational outcomes for children. Models 12, 15 and 18 (Table 4) look at the relationship between remittances and children's school performance. Net of other factors, the presence or the absence of remittances do not relate significantly with the educational performance of children.

A number of control characteristics and their overall impact on school performance are worth mentioning (Table 3 and Table 4). The results show that there is a negative association between school performance and being a girl in Ghana and Nigeria. Auxiliary analyses (not shown) tested a series of interactions between gender and the four transnational measures in each country context. None of the interaction terms were significant and there were no improvement of fit for the interacted models. Therefore, we concluded that there is no direct evidence of a moderating effect of child gender and transnational characteristics in relation to educational performance. Furthermore, we found a positive relationship between maternal education and the school performance of children in Ghana and Nigeria. Similarly, results show that children spending more hours doing homework are more likely to do well in school in Ghana and Nigeria.

\section{Discussion}

Migration is a solution for some parents in Africa to provide better opportunities for their children who stay behind. As more parents migrate however, there are concerns about the well-being of children in transnational care. Although parental absence comes with separation and loss, there are reasons to believe that staying behind does not always result in worse outcomes for children. Staying in the country of origin brings the advantage of familiar community and family networks, which may alleviate the negative consequences coming with parental departure. Yet, the vulnerability of children who stay behind should not be ruled out, especially when considering the need for parental input for children's development. The empirical scholarship to date provides mixed evidence with no studies so far targeting African countries. This study contributes to the literature in the following two ways: (1) we distinguish different types of parental migration (whether internal or international) and we consider the marital status of the migrant parent. This adds the context of marital dissolution as a form of life for children in transnational care when measuring educational outcomes and (2) we investigate different transnational family forms and how they associate with children's school performance. As such, we bring the complexity of life of children in transnational care into focus 
when assessing their educational outcomes. We discuss each of these two contributions in turn.

First, we asked if parental absence has a detrimental impact on children's school performance and we distinguish between parental migration when parents were in a relationship and parental migration when parents were divorced or separated. We found that children of divorced/separated internal migrant parents in Nigeria tend to perform more poorly in schools. This result echoes an emotional vulnerability to marital problems in the family found in previous research from Mexico and the USA (Amato and Cheadle 2005; Nobles 2011). At the same time, the international parental migration when parents are together was found to negatively impact children's educational performance in Ghana. Evidence from the Philippines suggests that large distances pose difficulties for international migrants in maintaining active parenting roles in the education of children who stay behind (Cortes 2015). In Ghana, the effects of transnational parental migration appeared when controlling for parental, family and schooling characteristics. The literature indicates that these factors are important mediators for children's school performance (Altschul 2012) and may explain differences in the outcome between Ghana and the neighbouring Nigeria. Our data show that the proportion of children with parents having secondary education or more is significantly lower in Ghana than in Nigeria. Furthermore, Ghanaian children live with more siblings at home, report worsen health and they do less homework when compared to children in Nigeria. In the context of parental absence, these conditions have the potential to negatively impact children's school performance.

Yet, the empirical paths found in Ghana and Nigeria were not reproduced in Angola, attesting Angola's specific context. In Angola, children with migrant parents, who are divorced or in a stable relationship, have no differing performance in schools compared to children in non-migrant families. This result is encouraging, especially when considering the trauma that Angolan society has experienced during and after a three-decade long civil conflict that ended in 2002. Although Angolan parents have lived in times of violence and deprivation, studies suggest that their primary concern was always to provide the best education for their children that they could find at home (Øien 2006). Furthermore, a study targeting Angolan migrants in the Netherlands found that this particular group, irrespective of the marital status, had a higher socio-economic status, often had the Dutch nationality and more often spoke the local language than other migrants in the country (Haagsman 2015). These characteristics may increase the social capital and the economic development of migrants but also of family members who stay behind in Angola. In particular, children in transnational care may benefit if resources are directed to fulfill their educational needs.

One finding was consistent in the three countries of this study: children with international migrant parents who are divorced do not have a differing performance in schools when compared to children in non-migrant families. This finding is important because the well-being of children in fragile families has been studied in the divorce literature in Western contexts (Amato and Cheadle 2005) but not much with respect to international parental migration. The few studies looking at divorce in relation to international parental migration have been conducted in Mexico (Creighton, Park, and Teruel 2009; Nobles 2011) and found that this type of absence disadvantages children in schools. 
This is not the case in our study. A likely explanation lies with the traditional family norms of living in Africa. In many countries across the continent, there is a culturally accepted norm for couples to live in multi-local residences, apart from their spouses, irrespective of migration (Mazzucato, Schans et al. 2015). Women in matrilineal communities such as Akan in Ghana where many migrants come from, enjoy a high degree of independence and keep separate budgets from their husbands. This feature of family life has been identified as a primary factor to the high incidence of divorce among Ashanti's in Ghana (Fortes 1950). In Angola, due to the extended civil war, many children were born outside a relationship and the reunification of parents was not always possible due to displacement, asylum seeking or migration (Øien 2006). As such, living apart is not only common for couples but also for many African children. Moreover, the circulation of children and kinship care is a natural way to raise children in many African countries and is part of a social system in which being a foster parent carries highly respected qualities such as kindness, solidarity and trust (Øien 2006). While parental proximity and marital union are important conditions for child well-being in other parts of the world, the social and family norms in Africa seem to ensure resilience against negative family events such as migration and marital dissolution.

A second contribution of this study relates to the diversity of transnational family forms and how they associate with the school performance of children whose parents migrated internationally and are in a stable marital relationship. The results show that overall, children in transnational care have no differing performance when compared to children in non-migrant households. One exception was noted in Ghana and Nigeria, where the migration of both parents is associated with less educational performance. This result is perhaps not surprising. The well-being of children is at the core of parental decision to migrate but the impact of migration on child well-being depends on whether families take proper measures to adjust for disruptions in children's lives when both parents are absent. Our results show that children do well when one parent migrates and the other parent is the caregiver but the care of a non-parental caregiver does not always substitute for the parental absence. Previous research noted that non-parental caregivers sometimes lack authority, which makes it difficult to provide guidance that children need (Lu 2012). Moreover, when parents migrate and children are left in the care of a non-parental caregiver, there are often high expectations for a better life from those who stay behind and for a continuous involvement of the migrant parent in the upbringing of the child (Mazzucato 2011). When these conditions are not met, disappointment and discord between the migrant, caregiver and child may follow, creating conflictual conditions that may affect children's school performance.

Nonetheless, the prevalent finding that parental migration does not seem to affect children's education can also be understood in the context of social parenthood and child fostering norms that are prevalent in the three African contexts. In the African countries in focus in this study, children do not associate parental absence with stigma, which was found to negatively affect the well-being of children in other geographical areas such as Southeast Asia (Parreñas 2005). The lack of negative outcomes is observed when children stay in a stable care arrangement and when one parent is the caregiver of the child when the other parent has migrated. Given universal concerns in the literature about maternal migration and the negative impact it has on children (Cortes 2015; Parreñas 2005), this 
does not appear to be the case in our study. While maternal absence might be a stressful condition, the context and the commonality of social parenthood norms in Africa may help children develop resilience and adapt to changing family configurations following maternal migration. Recent research conducted in a number of sub-Saharan African countries seems to confirm this argument (Mazzucato, Cebotari et al. 2015; Mazzucato, Schans et al. 2015; Mazzucato and Cebotari 2016).

Two additional findings are worth noting. In Ghana and Nigeria, girls are more susceptible to negative educational outcomes when compared to boys. However, parental education, especially the education of mothers is a significant determinant for increased school performance of children. These findings have an important policy component. Considering the significant role of gender in the education of children in Africa, more efforts may be needed to invest in girls who are more vulnerable to shocks, such as the absence of a parent that may affect their school performance. In addition, since the education of mothers is a significant predictor for improved education of children, it is important to invest in today's girls who will likely perpetuate the educational development of their children in a similar way.

This study is not without limitations. Migration does not occur randomly within a given population. Instead, there are a number of characteristics that may influence people's decision to migrate. Some observable factors that may influence the decision to migrate were included, such as maternal and paternal education and the living conditions. However, other indicators, such as children's pre-existing educational outcome could not be included given the cross-sectional nature of the data. As with all cross-sectional analyses, causal relationships cannot be assumed and as such, these results must be approached as exploratory. The samples employed in this study are not nationally representative because they were drawn from high out-migration urban locations. Hence, the findings cannot be generalised to all children in the country or to a region as a whole. Moreover, because data were gathered by asking children themselves, and since children had difficulties remembering specific dates, we were not able to collect reliable data on important mediating indicators such as the length of separation of the child from the migrant parent. We assume that older children in transnational families are more likely to be separated from their parents for longer periods due to their longer life spans. Finally, since data were collected in schools, we are not able to account for those children who live transnationally but have dropped out of school.

Nevertheless, the current study sheds light on the relationship between parental migration and the school performance of children in transnational care. The childparent separation does not automatically result in decreased school performance, but there are some risk factors that make children underperform in schools, such as having a non-parental caregiver while both parents are abroad. Some characteristics associated with parental absence may negatively affect children, but parental migration in itself is not a vulnerability for the educational performance of children who stay behind in the specific African context of this study.

\section{Disclosure statement}

No potential conflict of interest was reported by the authors. 


\section{Funding}

This work was supported by the NORFACE Research Program 'Migration in Europe: Social, Economic, Cultural and Policy Dynamics' [grant number NORFACE-315]; and the Netherlands Organization for Scientific Research, WOTRO Science for Development Division [grant number W01.65.316].

\section{References}

Adepoju, A. 2004. "Trends in International Migration in and from Africa." In International Migration Prospects and Policies in a Global Market, edited by Douglas S. Massey and Edward Taylor, 59-77. Oxford: Oxford University Press.

Almeida, V. M. 2010. Overview on South-South Migration and Development in Angola: Trends and Research Needs (Vol. ACPOBS/2010/PUB07). Brussels: ACP Observatory on Migration; International Organization for Migration.

Altschul, I. 2012. "Linking Socioeconomic Status to the Academic Achievement of Mexican American Youth Through Parent Involvement in Education." Journal of the Society for Social Work and Research 3 (1): 13-30. doi:10.5243/jsswr.2012.2.

Amato, P. R., and J. Cheadle. 2005. "The Long Reach of Divorce: Divorce and Child Well-being Across Three Generations." Journal of Marriage and Family 67 (1): 191-206. doi:10.1111/j. 0022-2445.2005.00014.x.

Antman, F. M. 2012. "Gender, Educational Attainment and the Impact of Parental Migration on Children Left Behind." Journal of Population Economics 25 (4): 1187-1214. doi:10.1007\% 2Fs00148-012-0423-y.

Battistella, G., and C. G. Conaco. 1998. "The Impact of Labour Migration on the Children Left Behind: A Study of Elementary School Children in the Philippines." Journal of Social Issues in Southeast Asia 13 (2): 220-235. doi:10.1355/SJ13-2C.

Brown, R., and B. Poirine. 2005. "A Model of Migrants' Remittances with Human Capital Investment and Intrafamilial Transfers." International Migration Review 39 (2): 407-438. doi:10.1111/j.1747-7379.2005.tb00272.x.

Carling, J., and M. Tønnessen. 2013. "Fathers' Whereabouts and Children's Welfare in Malawi." Development Southern Africa 30 (6): 724-742. doi:10.1080/0376835X.2013.859068.

Clemens, M., and E. Tiongson. 2013. Split Decisions: Family Finance When a Policy Discontinuity Allocates Overseas Work. Working Paper Number 324. Washington, DC: Center for Global Development.

Cortes, P. 2015. "The Feminization of International Migration and Its Effects on the Children Left Behind: Evidence from the Philippines.” World Development 65 (January): 62-78. doi:10.1016/j. worlddev.2013.10.021.

Creighton, M., H. Park, and G. Teruel. 2009. "The Role of Migration and Single Motherhood in Upper Secondary Education in Mexico." Journal of Marriage and Family 71 (5): 1325-1339. doi:10.1111/j.1741-3737.2009.00671.x.

Edwards, A., and M. Ureta. 2003. "International Migration, Remittances, and Schooling: Evidence from El Salvador.” Journal of Development Economics 72 (2): 429-461. doi:10.1016/S0304-3878 (03)00115-9.

Fortes, M. 1950. "Kinship and Marriage Among the Ashanti." In African Systems of Kinship and Marriage, edited by Alfred R. Radcliffe-Brown and Daryll Forde, 252-284. New York: Oxford University Press.

GDHS. 2008. "Ghana Demographic and Health Survey 2008." Accessed March 31. http://www. dhsprogram.com/.

Goody, E. 1982. Parenthood and Asocial Reproduction: Fostering and Occupational Roles in WestAfrica. Cambridge: Cambridge University Press.

Haagsman, K. 2015. "Parenting Across Borders: Effects of Transnational Parenting on the Lives of Angolan and Nigerian Migrant Parents in the Netherlands." PhD diss., Maastricht University. 
Hu, F. 2012. "Migration, Remittances, and Children's High School Attendance: The Case of Rural China." International Journal of Educational Development 32 (3): 401-411. doi:10.1016/j. ijedudev.2011.08.001.

INE. 2010. "IBEP-Angola: Inquérito Integrado Sobre o Bem-Estar da População. Luanda: Instituto Nacional de Estatística-Ministério do Planeamento.” Accessed December 12, 2013. https:// andine.ine.gov.ao/nada4/index.php/catalog/11.

IOM. 2010. Angola: A Study of the Impact of Remittances from Portugal and South Africa. Migration Research Series (Vol. 39). Geneva: International Organization for Migration.

Jordan, L. P., and E. Graham. 2012. "Resilience and Well-being Among Children of Migrant Parents in South-East Asia." Child Development 83 (5): 1672-1688. doi:10.1111/j.1467-8624.2012.01810.x.

Kandel, W., and G. Kao. 2001. “The Impact of Temporary Labor Migration on Mexican Children's Educational Aspirations and Performance." International Migration Review 35 (4): 1205-1231. doi:10.1111/j.1747-7379.2001.tb00058.x.

Kong, S. T., and X. Meng. 2010. "The Educational and Health Outcomes of the Children of Migrants." In The Great Migration: Rural-Urban Migration in China and Indonesia, edited by Xin Meng, Chris Manning, Li Shi, and Tadjuddin Nur Effendi, 97-120. Northampton, MA: Edward Elgar Publishing.

Levitt, P. 1998. "Social Remittances: Migration Driven, Local-level Forms of Cultural Diffusion." International Migration Review 32 (4): 926-948. doi:10.1080/1369183X.2011.521361.

Lu, Y. 2012. "Education of Children Left Behind in Rural China." Journal of Marriage and Family 74 (2): 328-341. doi:10.1111/j.1741-3737.2011.00951.x.

Mazzucato, V. 2011. "Reverse Remittances in the Migration-Development Nexus: Two-way Flows Between Ghana and the Netherlands.” Population Space and Place 17 (5): 454-468. doi:10.1002/ psp.646.

Mazzucato, V., B. v. d. Boom, and N. N. N. Nsowah-Nuamah. 2008. "Remittances in Ghana: Origin, Destination and Issues of Measurement.” International Migration Review 46 (1): 103-122. doi:10.1111/j.1468-2435.2008.00438.x.

Mazzucato, V., and V. Cebotari. 2016. "Psychological Well-being of Ghanaian Children in Transnational Families.” Population Space and Place. doi:10.1002/psp.2004.

Mazzucato, V., V. Cebotari, A. Veale, A. White, M. Grassi, and J. Vivet. 2015. "International Parental Migration and the Psychological Well-being of Children in Ghana, Nigeria, and Angola." Social Science \& Medicine 132: 215-224. doi:10.1016/j.socscimed.2014.10.058.

Mazzucato, V., and D. Schans. 2011. "Transnational Families and the Well-being of Children: Conceptual and Methodological Challenges." Journal of Marriage and Family 73 (4): 704-712. doi:10.1111/j.1741-3737.2011.00840.x.

Mazzucato, V., D. Schans, K. Caarls, and C. Beauchemin. 2015. “Transnational Families Between Africa and Europe.” International Migration Review 49 (1): 142-172. doi:10.1111/imre.12153.

McKenzie, D., and H. Rapoport. 2007. "Migration and Education Inequality in Rural Mexico." Integration and Trade Journal 27: 135-158.

McKenzie, D., and H. Rapoport. 2011. "Can Migration Reduce Educational Attainment? Evidence from Mexico.” Journal of Population Economics 24 (4): 1331-1358. doi:10.1007/s00148-0100316-x.

NDHS. 2008. "Nigeria Demographic and Health Survey 2008.” Accessed March 31. http://www. dhsprogram.com/.

Nobles, J. 2011. "Parenting from Abroad: Migration, Nonresident Father Involvement, and Children's Education in Mexico." Journal of Marriage and Family 73 (4): 729-746. doi:10. 1111/j.1741-3737.2011.00842.x.

Øien, C. 2006. "Transnational Networks of Care: Angolan Children in Fosterage in Portugal." Ethnic and Racial Studies 29 (6): 1104-1117. doi:10.1080/01419870600960370.

Parreñas, R. S. 2005. Children of Global Migration: Transnational Families and Gendered Woes. Stanford, CA: Stanford University Press.

Pillinger, J. 2007. The Feminisation of Migration: Experiences and Opportunities in Ireland. Dublin: Immigrant Council of Ireland. 
Poeze, M. 2016. “The Costs of Breadwinning: Legal Status, Finances and Ghanaian Transnational Fathering." In Family Life in an Age of Migration and Mobility, edited by Majella Kilkey and Ewa Palenga-Möllenbeck, 149-170. Hampshire: Palgrave Macmillan.

Rapoport, H., and F. Docquier. 2006. “The Economics of Migrants' Remittances.” In Handbook of the Economics of Giving, Alturism, and Reciprocity, edited by Serge-Christophe Kolm and Jean Ythier, 1135-1198. Amsterdam: Elsevier.

Schmalzbauer, L. 2004. "Searching for Wages and Mothering from Afar: The Case of Honduran Transnational Families.” Journal of Marriage and Family Process 66 (5): 1317-1331. doi:10. 1111/j.0022-2445.2004.00095.x.

Smith, A., R. N. Lalonde, and S. Johnson. 2004. "Serial Migration and Its Implications for the Parent-Child Relationship: A Retrospective Analysis of the Experiences of the Children of Caribbean Immigrants." Cultural Diversity and Ethnic Minority Psychology 10 (2): 107-122. doi:10.1037/1099-9809.10.2.107.

UNDP. 2009. Overcoming Barriers: Human Mobility and Development. New York: UNDP. http:// hdr.undp.org/sites/default/files/reports/269/hdr_2009_en_complete.pdf.

UNHCR. 2014. UNHCR Global Appeal 2014-2015. Geneva: United Nations High Commission for Refugees. http://www.unhcr.org/ga14/index.xml.

Wen, M., and D. Lin. 2012. "Child Development in Rural China: Children Left Behind by Their Migrant Parents and Children of Nonmigrant Families.” Child Development 83 (1): 120-136. doi:10.1111/j.1467-8624.2011.01698.x.

Yang, D. 2008. "International Migration, Remittances, and Household Investment: Evidence from Philippine Migrants' Exchange Rate Shocks.” The Economic Journal 118 (528): 591-630. doi:10. $1111 /$ j.1468-0297.2008.02134.x. 